\title{
CANADIAN ANAESTHETISTS' SOCIETY SYMPOSIUM ON RESPIRATORY CARE
}

KING EDWARD SHERATON HOTEL, TORONTO, ONTARIO, SUNDAY, JUNE 15, 1969

\section{Programme}

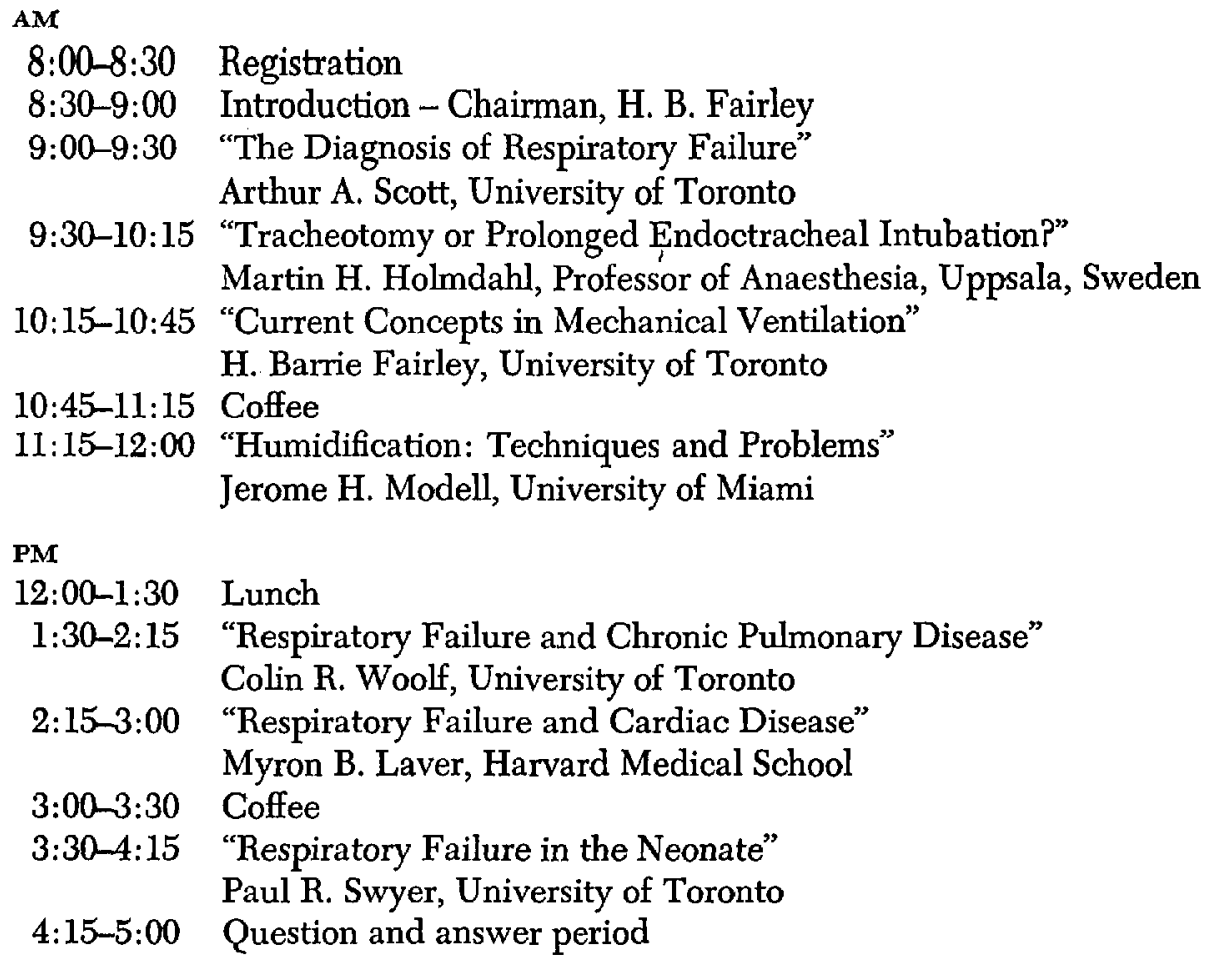

